\title{
Insecticide Resistance versus Antimicrobial Resistance. Biological Issues in Historical Perspective*
}

Christian W. Simon

\section{Summary}

The developments of insecticide resistance in insects and antimicrobial ${ }^{1}$ resistance in bacteria seem to have not too many aspects in common, due to the diverse nature of eukaryotes and prokaryotes cells and organisms. However, there are several approaches, both in the history of ecological systems and in the History of Science ${ }^{2}$, that can successfully be applied to explain aspects of developments shared by both phenomena of resistance. Looking back to a century of discoveries, scientific explanations, industrial, agricultural, and medical practice, the historian is especially well placed for investigating the lessons to be learned and to be exchanged at the boundaries of research on resistant insects and microbes.

\footnotetext{
* The Swiss National Science Foundation offered a grant for the research on the history of insecticide resistance research, conducted by John S. Ceccatti and the author. Gordon Cain and the Chemical Heritage Foundation (Philadelphia) offered a one-year fellowship to the author for studying aspects of corporate strategies in the insecticide industry. The Hagley Museum and Library, Center for the History of Business, Technology, and Society (Wilmington) offered a grant-in-aid for research on the history of the agricultural business. Angela N. H. Creager, Princeton University and Institute for Advanced Studies, discussed a first draft of her findings on the history of antibiotic resistance research (see Creager 2002) with John S. Ceccatti and the author. The author thanks both, as well as Jean-Claude Piffaretti, President of the Steering Committee to the Swiss National Research Program on Antibiotic Resistance (NFP 49), for their helpful comments on earlier versions of the present article.

1 I use the term 'antimicrobials' for all kinds of pharmaceuticals targeted at microbes, especially sulfa drugs and antibiotics.

2 "History of Science" (uppercase) is used in this article as a term for the specific discipline dedicated to the study of the origins and developments of modern biology, characterized by its own approaches, paradigms, and narratives. It is considered here as an established tradition of teaching and research different from social studies of science and technology ("STS") which have sociology of science as their core discipline.
}

Christian W. Simon, Department of History, University of Basel, Hirschgässlein 21, CH-4051 Basel (christiansimon@tiscali.ch). 


\section{Introduction}

An overview of the scientific, but also of the science history literature shows that specialists dealing with insecticide resistance usually have had no contacts with specialists interested in antimicrobial resistance and vice versa. Is this the result of scientific specialization, the formation of disciplines and subdisciplines? Or do the two subjects really have nothing in common, except the name, and the layperson is a victim of seeing similarities because their names are similar? In fact, the biology of bacteria is quite different from that of insects, and a specialization in microbiology is needed to understand the main factors behind resistance, the molecular biology of heredity in prokaryotes like bacteria, as well as an advanced understanding of eukaryotes cells is a precondition for dealing with resistant strains of insects.

In writing the following sketch, I assume that both sides would actually be interested in learning from each other, especially with regard to the history of scientific knowledge, but also to the history of unwanted or unexpected side effects of biotechnologies. Therefore, neither the scientific interest in the current knowledge nor the eagerness to learn how resistance is explained today are at the outset of the linking of the two subjects that I advocate, but 'meta'-questions: how knowledge emerges and transforms itself from group to group and from decade to decade, from context to context; or how resistance influences ecosystems and is shaped in turn under the influence of an environment that is partially 'natural', partially man-made. No attempt will be made to discuss the role of the regulation of antimicrobials and insecticide applications in detail, but its effects will be mentioned where needed.

\section{History of knowledge on drug resistance ${ }^{3}$ and insecticide resistance - a sketch}

Since in the following pages, we will discuss mainly questions of historiographical approaches, some basic information on the actual development of knowledge on antimicrobial and insecticide resistance may be helpful ${ }^{4}$. However, only an abbreviated presentation can be given here, the detailed

3 For the purposes of this article, 'drug resistance' is used synonymously with 'antimicrobial resistance'.

4 For a general introduction on the biology of resistant microorganisms, see Amábile-Cuevas 2003, 138-141, Chadwick/Goode 1997, Levy 1992, and Lewis 2002. For resistant insects, see Sjut 1997, McKenzie 1996, Pimentel 1993, Brown 1996, and Roush/Tabashnik 1990. 
reconstruction and explanation of events and processes being the subject of other essays 5 .

When the first experiments with bacteria cultures were conducted in the last decades of the 19th century, the researchers already noticed that the dyes they used for coloring and identifying species of microbes, killed some strains, while others survived the dyeing experiments. The specialists accepted this as a matter of fact as long as they did not adhere to a concept of heredity based on constant species in bacteria. When the first generation of antimicrobial drugs, organo-arsenical compounds for which Paul Ehrlich's Salvarsan was paradigmatic, were introduced early in the 20th century, scientists were not too much surprised that the microbes usually killed by such synthetic "chemotherapeutica" sometimes failed to respond as expected. The next generation of antimicrobials were the sulfa drugs, introduced during the 1930s following the pioneering work undertaken by I.G. Farben and associated with the name of Gerhard Domagk. Already in 1939, even before the massive and sometimes preventive applications of sulfa drugs in the military medical practice during the Second World War became common, scientific journals published articles on bacteria resistant to sulfa drugs. When penicillin, representing the first generation of antibiotics, became accessible for the treatment of military personnel around 1943 in U.S. and British hospitals, the new drug was also welcomed as an answer to wound infections caused by bacteria already resistant to several sulfonamides. After 1945, news on penicillin-resistant bacteria were soon published in the specialized journals, and, a few years later, the same happened with penicillinderived drugs.

In the 1950s, the popular press featured alarming stories on microbes "firing back" against $\operatorname{man}^{6}$, and in the 1960s, hospital infections caused by resistant strains present in hospital buildings and in the bodies of the medical personnel became a common issue. At the same time, the use of antibiotics on animal farms reached a level that was of concern to the specialists fearing a transfer of resistance genes from microbes in cattle and poultry to bacteria living on and in humans. With inquiries commissioned by the British government and published as the Swann Report in 1969/70, a series of public warnings was started ${ }^{7}$. The medical profession, but also the World Health Organization ${ }^{8}$, were concerned about ever more difficulties to

5 On the history of antibiotic resistance, see Creager 2002 (forthcoming). I thank the author for having shared a first draft with me in October 2002. The history of insecticide resistance knowledge is the subject of forthcoming articles by John S. Ceccatti.

6 U.S. Congress 1995, 167 f.

7 A. H. Linton, "The Swann Report and its Impact", in: Stuart-Harris/Harris 1982, 183-194.

8 World Health Organization 2000. 
fight infectious diseases like tuberculosis on a global scale. They responded by proposing codes of conduct, while some governments banned the use of antibiotics on farm animals that were also used on humans.

Although the scientific fact of drug resistance in bacteria was accepted from the beginning, explanations were hard to find during the first half of the 20th century. Or rather they were, for a long time, based on contradictory assumptions, and only in the 1960s were the basic mechanisms of acquiring and transferring resistance between bacteria understood.

Insects resistant to insecticides were first described in American scientific journals at the end of the 19th century. A rather small number of "economic entomologists" continued to report on such cases until the 1930s, always from the U.S. The stage of scientific knowledge of the time did not allow for more than a general hypothesis on selection and heredity. Although in retrospect, this hypothesis was easier to accept for eukaryotes like insects than for prokaryotes like bacteria (since in the laboratory, insects like Drosophila melanogaster obeyed the 'laws' of heredity), many authors denied that insect resistance was a scientific fact, pointing at explanations like humidity and other circumstances occurring in the field. Theodosius Dobzhansky offered in his book on Genetics and the Origin of Species in 1937 an explanation based on population genetics. From the 1920s some researchers had worked on resistance, in the field but also by reproducing resistant strains in the laboratory, developing standardized tests of susceptibility and animal models.

This remained a specialist's knowledge until in 1946 DDT, introduced only a few years earlier as an agricultural pesticide ${ }^{10}$, failed massively due to resistant strains of flies and other pests selected by the action of the insecticide during two to three seasons of application. When the modern synthetic insecticides became a standard element of commercial agriculture, insecticide resistance was, by the 1950s, a major concern of economic relevance to farmers and producers of insecticides, but also to the United Nations (FAO, WHO) and local officers in charge of public health programs depending on insecticides.

The basic mechanisms were understood by combining insights from population genetics with those from biochemistry of enzymes. Scientific research, however, did not generate a knowledge on which industrial solutions of the problem could be based. Like in the case of drug resistance, lists of dos and don'ts were the main means offered by scientists to farmers for delaying

9 On Dobzhansky, see Ceccatti "Natural Selection" (forthcoming).

10 DDT remained reserved for military hygiene purposes until summer 1945 in most countries participating in the Second World War. However, in neutral countries like Sweden, Switzerland or Spain, it was used in agriculture from 1942 against the Colorado beetle, rapeseed pests, and also against flies in cattle stables. Simon 1999. 
and hopefully avoiding resistance in the field. This approach was combined with a new definition of the 'ideal insecticide' and 'best practices' of its application: a nonpersistent substance, well targeted to selected species, and used in the right moment of the year under the supervision of applied biologists, and in more recent recommendations combined with "biological" or "organic" methods of insect control.

\section{Part one}

\section{Ecological and systemic approaches}

The first historiographical approach that I test on its practicability to discover similarities or parallels between the history of both insecticide and antibiotic resistances I want to call "ecological". This term does here not designate a political movement, but a group of scientific approaches dealing with relationships between populations of different species and thinking in interrelated systems as developed in the late 19th century ${ }^{11}$.

The second approach is conceived in terms of technology, but closely related to the concepts of ecology. The use of antimicrobials in our bodies as well as the use of pesticides in the field are kinds of biotechnologies belonging to wider contexts or technological systems. As such, they are interesting under the aspect of unexpected "side effects", the old theme - not of "nature firing back" been unforeseeable, probably just because the technologist/engineer narrows his focus down to "what it does", not to "what else happens under its application" 13 . Both phenomena, insect resistance and resistant microbes, appear in the context of the massive application of biologically active substances in fields that are best described as "integrated nature-technological systems". In the light of such interactions humans are "hybrids" made of applied biology and chemistry. They appear as bodies wanting to be healthy and be fed from products of agriculture based on chemistry and applied biology.

11 Trepl 1987. Trepl 1992. Spencer 1999.

12 The idea of "nature firing back" implies a dichotomy between "man" and "nature", a view to be overcome by developing concepts of interdependence in the sense of technologies embracing humans, their artifacts (here: molecules made or extracted by industry) as well as living beings from microbes to cattle and poultry. American Academy 1999. Law 2000.

13 The risk of not yet arrived, but expected and feared side effects asks for a risk assessment and for policies of handling such risks by technological discourses. Cf. Böschen 2000, Böschen 2002. On resistance risk assessment, see European and Mediterranean Plant Protection Organisation 2002, U.S. FDA 1999, Vose 2001, Leonard (s.a.). 
Insect resistance in agriculture is a side effect of a chemical-based technology of food production. Insecticides form a part of an entire system, made of (mostly manipulated, selected or genetically modified) plants, (treated) soil, farm machinery, fertilizer, means of transportation and storage (including refrigeration and air-conditioning), but also insects, weeds, and, of course, farmers and their partners providing and receiving products, knowledge, services, etc. ${ }^{14}$ Insecticides are an integrated part of this system to control pest insect populations that otherwise would reduce productivity or make the whole technology of intensive farming economically impossible. In the light of this approach, resistance is a problem generated by the technology applied itself - and calling for related "technical fixes" 15 in turn ${ }^{16}$. We can extend this approach to hygiene systems like fly control in the household, or cockroach fighting in the restaurant, to hospital hygiene, or to even more complex systems like malaria control. The latter would be especially interesting because "resistant malaria" combines both aspects, plasmodia (microorganisms) resistant to drugs, and insects (vectors) resistant to insecticides ${ }^{17}$.

Drug resistance is part of a health technology, itself based on antibiotics and sulfa drugs, but reaching back to the first applications of disinfectants in the mid-19th century. From the time when the first sulfa drugs appeared in the mid-1930s, in only a few decades, human life expectancy grew by many years ${ }^{18}$. We use antibiotics to control bacterial infections, and we create especially in hospitals - a man-made environment of which antibiotics and therefore resistant microbes form a part ${ }^{19}$. We can expand this idea of a health system to include the health aspects of the above-mentioned system of intensive food production, i.e. the keeping of farm animals in a way only possible thanks to drugs. Antibiotics are used for two purposes inside these food-production technologies: for accelerating and enhancing the buildup of muscular mass, and for controlling diseases under the crowded conditions typical of the "intensive" growing of animals ${ }^{20}$.

14 Pimentel 1993, Bosso 1987, Perkins 1982, Whorton 1974.

15 On the concept of technological fixes, see the Hagley Seminar of October 4, 2002, www. hagley.lib.de.us/center20021005.html. Rosner 2004.

16 Clarke 1997, Sjut 1997, Georghiou 1986, McKenzie 1996, Roush/Tabashnik 1990.

17 The current literature on resistant malaria mainly discusses the resistance of plasmodia towards antimalarial drugs. Formerly, mosquitoes resistant to insecticides were a major concern for organizations in charge of malaria programs like the WHO during the 1950s and 1960s. Doberstyn 1984, 468f. For a regional example of anopheles ecology, see Palsson 1999.

18 Between 1935 and 1955, due to the introduction of sulfa drugs and antibiotics, the median life span increased from 62 to 70 years. U.S. Congress 1995, 39.

19 See articles in British Journal of Medicine 317,1998 (special issue on drug resistance). Bryan 1984, Hughes/Andersson 2001.

20 British Journal of Medicine 1998 (Johnston). 
This extension of the technological approach is far from being merely rhetorical. Bacteria can exchange genes across species boundaries and also between microbes living in animals and their cousins living in our bodies. Animal health antibiotics do not only affect humans through residues and continue to exert selective pressure on strains of microbes, but resistance genes can also be transferred from microbes living in animals or meat to those living in humans. ${ }^{21}$ The antibiotic-based biological technology system encompasses animals as well as humans: the latter are not the masters of, but just part of microbial ecological systems.

Through such systemic approaches the historian discovers many aspects that the history of drug resistance shares with that of insecticide resistance.

(a) First, there is a common biological ground for resistance as a side effect generated by the technological systems. Both, insect resistance as well as resistant bacteria, are products of selection processes under the stress caused by a biocide substance onto populations of living organisms. They may be or not be the targets of chemical attacks on what is considered as "pests", i.e. organisms living in the "wrong" place or in too large numbers for human needs or causes/vectors of diseases. In both cases, heredity is at the base of the reproduction and spread of resistance. Therefore, the pace of generational reproduction is part of the explanation why some species show resistance earlier, others later. We come back to the biological explanations when we will discuss History of Science approaches in Part two of the present article.

(b) Second, by historically analysing the dynamics of these systems, we discern how scientific insights influence (or do not influence) the spontaneous responses to resistance. In most cases, the first "fix" that was tried in response to resistance was increasing the doses (or the concentrations) of the insecticide or the drug, without an appropriate scientific background for doing so. The next "fix" was applying another chemical compound hoping that this one was still effective. This fix fitted the dynamics of industrial innovation well, as long as the pharmaceutical and the agrochemical industries ${ }^{22}$ were able to offer products based on new compounds at rather short intervals of time. When, especially after 1965, industrial research and development activities became more expensive and the regulative network imposed by public opinion and state offices prohibited marketing new products as fast as before, this could no longer be the main response to resistance. The third

21 On the research conducted in the 1970s, see Crawford/Shotts 1982, 173f. The more recent developments are summarized in Amábile-Cuevas 2003, 138, 143.

22 In the U.S., for many decades of the 20th century, the pharmaceutical industry was considered as an industrial branch in its own right. In Europe pharmaceuticals in the 20th century were very often products of general chemical companies or dyestuffs companies. 
"fix" had therefore to be based on ecological and biological insights in addition to those necessary for finding new active compounds: ecology had to be respected in order to learn how to "mitigate" resistance. For drug resistance, the effective respect for ecological inputs started around 1970. For agricultural effects of resistance, the corresponding movement was made ca. a decade later.

\section{Economics of resistance and innovation}

A systemic approach should include the economics of the technology under study. Insect resistance, for a short period of time, got a lot of attention for its effects on agriculture, public health, and corporate economy when after the Second World War the first group of affordable and successful synthetic pesticides were introduced and widely used as a new element of agricultural technology. This was the panic caused by the discovery of DDT resistance in $1946^{23}$. However, from the mid- or late 1950s onwards, it was established that there was no final response to insecticide resistance that could immediately interest the chemical industry. As this industry became aware that no competitor had, in the short term, any advantage to gain over the other through resistance research (because resistance appeared with every pesticide then imaginable), resistance research went back into the realm of academic research (and state experiment stations) where it had come from.

During the late fifties and the 1960s, the golden age of prosperity and continuous growth in western Europe, resistance, be it insect or microbe resistance, was relegated to the margins of general scientific knowledge relevant to industrial research and development. A period of new concerns was needed, of ecological concerns this time, around 1970, to rediscover resistance as a serious problem. As far as insects are considered, such concerns began to become manifest already in the 1960s, the ban on DDT being one of the more visible political effects of $\mathrm{it}^{24}$. Already around 1970, policies of drug application in humans ${ }^{25}$ and farm animals ${ }^{26}$ were criticized for too easily leading to resistance ${ }^{27}$. While the practices of "animal health" did not

23 National Academy 1951, Buxtorf/Spindler 1954.

24 Simon 1999.

25 Stuart-Harris/Harris 1982, Bryan 1984, British Journal of Medicine 1998 (Carbon, Farmer, Struelens, Goossens).

26 British Journal of Medicine 1998 (Johnston).

27 Creager 2002, 39: "Antibiotic resistance is increasingly conceptualized as an environmental problem. [...] Since the 1960s, drug resistance as a scientific problem has grown to involve a broader swath of scientists, particularly as the studies of the ecology and evolution of drug resistance have gained ground." Levy/Novick 1986, xiiif. 
change for some years, hospitals developed codes of conduct for reducing the risks inherent to resistant microbes in their context at an early time.

Insect resistance became at least a decade later the object of similar policies $^{28}$. Partially through the action of industry's IRAC, created in $1984^{29}$, partially thanks to readers for applied entomologists and textbooks for ecologists of the early $1990 \mathrm{~s}^{30}$, means of avoiding or retarding insect resistance became common part of insecticide-related knowledge.

To some extent, the development of a coherent, urgent international research agenda on insect resistance was delayed by geographical factors. Economically relevant insect resistance was a problem confined to North America almost for half a century (roughly, 1900 to 1950). Even today, many regions of European agriculture (in contrast to orchards, greenhouses and the like) do still not experience serious insect resistance problems ${ }^{31}$. However, with the introduction of insecticides to monocultures (cotton, rice), the regions, for which resistance is an urgent issue, have encompassed, especially since the 1960s, important parts of Africa and Asia. Similar effects were reported from the 1950s for resistant vectors of diseases such as malaria mosquitoes, when international public health agencies tried to eradicate these insect species.

The stimulus for establishing an (informal) international research agenda was lacking before ca. 1950. Thereafter, progress in industrial organic chemistry generated prospects to find ever new compounds to combat resistant insects. Therefore, a coherent agenda of insect resistance research actually started only after the Second World War. With the exception of a short period, the industry participated less actively in this research effort than the universities. Then, of course, the insights of several disciplines as well as research techniques began, step by step, to make their contribution to a multidisciplinary effort of practical "problem solving". Institutions of research that were multidisciplinary by nature like the agricultural state experiment stations were well placed for responding to these needs.

28 Roush/Tabashnik 1990, Pimentel 1993, Clarke 1997.

29 The creation of the Insecticide Resistance Action Committee IRAC marked a renewed corporate interest in resistance research. See http://plantprotection.org/irac.

30 Roush/Tabashnik 1990; Townsend 2000, 444.

31 Interview with Dr. Pierre-Joseph Charmillot, Changins, RAC experiment station in Switzerland (Station fédérale de recherches en production végétale), 2002. 


\section{Drivers of research}

Push factors for developing a truly international research agenda on drug resistance lay in the discovery of hospital-inherent resistant strains of microbes and their effects. Hospital infections that had no cures in the repertoire of then common antibiotics became of concern, also public concern, by the mid-1950 $\mathrm{s}^{32}$. Of course, this also looked like an economic disaster, because patients had to stay longer in hospitals. On the other hand, medical doctors and hospitals feared legal action for malpractice from patients if they did not apply a prophylactic antibiotics treatment ${ }^{33}$.

On the insect resistance side, a decisive impulse for shifting the research agenda towards more ecological approaches came from the then latest and best-engineered insecticides, the synthetic pyrethroids that selected resistance at an astonishingly fast pace. During the 1960s manufacturers of insecticides had usually been happy with the resistance problems troubling their competitors, because they were able, at least for a few years, to sell a new insecticide formula against which insects had not yet found the answer ${ }^{34}$. But after 1970, the whole industry became concerned. At the same time, growing corporate research and development expenses for new insecticides already had become more and more of a problem, and state regulation helped to slow down innovation rhythms further, as the industry believed. A bit more than a decade later, by 1984, the industry had created IRAC and started two policies in one: showing that it cared about resistance (ecological responsibility), and exchanging precompetitive knowledge on resistance between their corporate laboratories. Global leadership in actions against the effects of drug resistance was taken by the World Health Organization, with a report on the state, causes and consequences published in $2000^{35}$. Academic as well as cooperative research initiatives can be found in several countries around the same year ${ }^{36}$.

The tactics of avoiding or slowing down the development of resistant strains and their emergence into dimensions relevant to corporate, national or global economy or public health are similar for both, insecticide resistance

32 U.S. Congress 1995,167f.; Wolstenholme 1958.

33 U.S. Congress, OTA 1995, 75. For more recent legal concerns related to resistant bacteria present in hospitals, see Fidler 1998.

34 Several mentions in documents at Monsanto archives (Washington University Library, St. Louis), Geigy archives (Novartis International AG, Basel).

35 World Health Organization 2000, see also the Canadian Committee on Antibiotic Resistance, www.ccar-ccra.org.

36 Lode 2001 (Germany). Swiss National Science Foundation 2000 (Switzerland). American Academy 1999 and U.S. Interagency Task Force on Antimicrobial Resistance 1999 (USA). Belgian Biosafety Server 2001. 
and antibiotic resistance: use with moderation, target well, use only when necessary, but then build sufficient concentrations, give preference to mixtures, monitor resistance for early detection, initiate awareness programs for users of the products, and, above all, design and implement codes of conduct, for the industry, for the farmer, and for the hospital and the medical doctors. The development of new chemical compounds with different modes of action and/or stepping back to older compounds that have not been in use for some time are also part of the current recommendations.

We still live in a period of slow innovation in the field of insecticides, although probably new "molecular" drug design now opens the way for antibiotics with really new ways of action. Most of the current tactics depend on the aforementioned basic biological characteristics of resistance: to understand selection and inheritance, and to find a way to avoid highly effective, unidirectional selection stress factors. These tactics make use of economically relevant aspects of ecological thinking, providing biological insights transformed into dos and don'ts applicable by producers and consumers of pesticides and antibiotics, respectively.

\section{Part two}

\section{Resistance as an object of the History of Science}

Resistance as an effect of selection and heredity is the outcome of two developments of the past. (a) The first one is the history of application modes and application intensity inside the aforementioned systemic frameworks. The interaction between this first history and (b) the second, namely the History of Science, is not yet clear in this case. Partially, it depended on the location of scientific activities - corporate laboratories, academic research facilities, or state experiment stations. Corporate research agendas were more problem driven that their academic counterparts, and, at least for insecticide resistance, some criteria governing the corporate scientific activities are discernible.

Companies invested in resistance research as long as they could hope to find a company-owned solution to the problem, and they did so only after resistance had become an economically relevant problem to their customers. Agricultural chemicals producers followed this pattern in the late 1940s and the 1950s. As these hopes failed, resistance became a secondary priority on the corporate agendas ${ }^{37}$. When the pace of innovation slowed down in the

37 Ceccatti, “Biological Research” 2004. Simon 1997. 
research focused on new compounds, resistance research on already existing (old) compounds was ranked higher again by the companies. For insecticide resistance this became visible with the creation of the IRAC network in 1984. For drug resistance the history of industrial (corporate) research has not yet been investigated.

\section{Combining different 'strains' of knowledge}

What we learn about research on resistant insects from the History of Science usually belongs to the history of academic research and, to some extent, also to the history of the activities of state experiment stations. For both cases, some of the main paradigmatic questions and explanations of the History of Science apply ${ }^{38}$. A powerful factor for the slowing down or speeding up of scientific progress are relationships between different fields of knowledge. Angela Creager is right in stressing the very difficult relationships between geneticists on the one hand and 'traditional' biologists, who insisted on spontaneous variation of bacteria in the case of drug resistance, on the other ${ }^{39}$. Another major disciplinary divide separated "organismic" biologists following the traditions of natural history from "new biologists" working under the influence of paradigms derived from physics ${ }^{40}$.

If we assume that a sound scientific approach to resistance has eventually to combine all these strains of knowledge, but also to include what the History of Science concentrating on laboratory science sometimes forgets, ecology ${ }^{41}$, an approach asking when and why the two "cultures" of biologists came to a mutual understanding, is a powerful tool in historiography. It is more than a rhetorical trick that makes Angela Creager's story go: the explanations of insecticide resistance as well as of antibiotic resistance needed a push, a leap that was only possible when physiology could finally be linked to genetics and vice versa. This was the case in the 1950s for insecticide resistance research, and in the 1960s for resistant bacteria.

For Angela Creager, the history of drug resistance basically "ended" with this convergence of two types of biological knowledge. In this "happy ending" of what appeared to be, in the eyes of the specialists of rhetoric, a "comedy" both sides admitted their own errors and the partial truths found by the

38 Olby 1990, Serres 1995.

39 Creager 2002.

40 Lutz 2002, Morange 2000, Stent/Calendar 1971, Kellenberger 1970. The classical text is Mayr 1982.

41 Matagne 2002.

42 White 1987. 
former opponents. Story-telling in the "comedy" mode applies to both subjects when viewed from the History of Science perspective.

\section{Dogmatism and progress in science}

There was also the element of dogmatism hindering scientific progress: the dogma of the constancy of species, however "progressive" itself as an instrument in the overcoming of Lamarckism after 1900, was an obstacle to the acceptance of changing properties of certain strains inside a species on the insect side of this affair ${ }^{43}$.

On the microbe side of the comparison, the opposite dogma of bacteria and other microorganisms being able to "adapt" themselves to environmental conditions, or in other words, remains of Lamarckism, fuelled the argument of those microbiologists who, until after the Second World War, were not willing to admit that classical genetics applied to bacteria ${ }^{44}$. In this case, a dogma similar to the one on the constancy of insect species hindered the evolution of bacteriology in the 19th century before adaptationism became the leading school for the first decades of the 20th century. This "monomorphism" 45 shows that we should not expect to discover necessarily parallel developments by comparing the history of insecticide resistance to that of drug resistance.

A basically correct assumption can be helpful or not for the progress of science, depending on the time when it becomes widely accepted in scientific communities. However, in both cases remains of Lamarckian ideas help to explain the opposition between geneticists and adaptationists on the one hand, and between more advanced entomologists and sceptics denying resistant insects the right of being considered scientific facts on the other hand.

A new element, reaching beyond the realm of the History of Science focusing on pure science, was brought forward by renowned geneticists in order to fight adaptationists in bacteriology. The Lysenko affair offered an opportunity to criticize adaptationism as a politically incorrect assumption related to communist beliefs ${ }^{46}$.

43 On Mendelian and later genetics, see Mayr 1982, 727f. (rediscovery of Mendel), and Mayr 752f. (Morgan and drosophila genetics). Instead of "Lamarckism" the term "soft inheritance" would be more appropriate, Mayr 1982, 793f. The best account on the history of drosophila genetics is Kohler 1994.

44 Creager 2002, $4 \mathrm{ff}$.

45 Amsterdamksa 1991, Gradmann 2000.

46 Lubrano/Solomon 1980, Krementsov 1996 and 1997. 
However, beyond the topos of the History of Science that the crossing of boundaries was necessary in order to make a step forward in science, was there any real insight to be gained at the boundaries between genetics and traditional microbiology, between new (reductionist) biology ${ }^{47}$ and natural history that actually guided research and development towards new solutions of the resistance "problem"? Before genetic engineering was successful ${ }^{48}$, was the New Biology of the Delbrücks and Lurias relevant to scientists willing to change the world in favour of the "conditio humana", as most industrial scientists and many academics, too, believed they had a mission for? The sometimes narrow focus of the history of academic biology makes it difficult to ask what consequences the insights under study had at the boundaries between science and action. Here ecology should enter the History of Science narratives. Though eventually well understood, resistance, in both cases, remained in the perspective of the History of Science a laboratory curiosity - except for the "ironic" application this knowledge had found in the routine of the New Biologists selecting strains of microbes by marking them with antibiotics resistance, as Angela Creager shows ${ }^{49}$.

A perception of an ecological malaise is needed to put resistance on top of the research agenda, and this happened at least twice in the history of insecticide resistance ${ }^{50}$, and probably twice, too, in the history of resistant microbes $^{51}$. This malaise was more than a feeling, it acted as an economic constraint for manufacturers and producers of food, and health, respectively.

Actually, resistance research was considered a necessity since sulfa drugs and penicillin had been selecting resistance during the Second World War, and since DDT, the paradigmatic representative of modern insecticides, had been selecting resistance in more and more insect species since 1946. The driver behind this research was the fear that resistance would one day end the viability of the chemical-based health and food technologies mentioned

47 By "new biology" I understand a group of tendencies in the history of biology originating from the application of (reductionist) approaches borrowed from physics and other "hard sciences' to the "secrets of life" opening the way to modern molecular biology. For an example of the historical relationship between 'traditional' biology (or 'natural history') and 'new biology' in a national academic context, see Stettler 2002.

48 Hohlfeld 1994.

49 Ceager 2002, 44f.

50 (1) When DDT failed due to selection of resistance after 1946; (2) when the synthetic pyrethroids selected resistance faster than expected around 1970.

51 (1) When resistance against sulfa drugs and penicillin was discovered from 1939 to the second half of the 1940s; (2) when the risk of genetic resistance information transfer between different species of bacteria was taken into consideration around 1970 . 
above. As soon as sufficient quantities of penicillin had become available, the medical profession greeted this new drug as a way out of the sulfa resistance "trap". Military medicine had led into this trap by applying sulfa drugs in mass prophylaxis programs ${ }^{52}$. As we know, penicillin resistance had become a common subject of medical papers by ca. $1945^{53}$.

However, we do not learn from the History of Science literature if this was considered to be a mere academic or ethical problem or also one that concerned the pharmaceutical industry. Schnitzer and Grunberg's book on drug resistance, published in New York in 1957, seems to be a result of corporate research or at least of a corporate review program at the Roche company's research laboratories in Nutley, N.J. ${ }^{54}$. But further research is necessary to determine the contribution of the industry to drug-resistance research. Anyway, the profession "got used" to the idea of resistance, applied higher dosages, and switched from time to time to new antibiotics ... until ecology was seriously put onto the agenda around $1970^{55}$.

\section{The making of scientific facts}

Another major question of the History of Science aims at learning when and under what circumstances a phenomenon or observation becomes a scientific fact ${ }^{56}$. Once more, the same question applies to both cases, with interesting results. However, the stories are very different. Acceptance for drug resistance as a scientific fact was prepared a few decades before 1900 by the first microbiologists and their pupils. Then the masters of chemotherapy like Paul Ehrlich accepted resistance towards their drugs as part of the world of facts before 1910 without hesitation ${ }^{57}$. When the first sulfa drugs became available in the 1930s, the medical researchers dealing with these compounds were almost immediately aware of resistance as a fact naturally linked to

52 Dowling 1977, 112. In the early U.S. penicillin program (ca. 1943), penicillin was given to patients suffering from infections resistant to sulfa drugs with priority, Pieroth 1992, 38f.

53 The first publication on bacteria resistant to sulfa drugs appeared in 1939. The first one on penicillin resistance is from 1940 resp. 1941. See also Frisch 1943, Schmidt/Sessler 1943, Hamburger 1943. The first publication on streptomycin resistance dates from 1946. The first comprehensive review article on failing antibiotics was Bailey/Cavallito 1948. See also the memories of Stollerman 1993 and Austrian 1999.

54 Schnitzer/Grunberg 1957. These authors worked at the Hoffmann-La Roche (Roche) research facility at Nutley, N.J., where they belonged to the Department of Chemotherapy.

55 Sabath 1982, 17f.

56 Fleck 1979.

57 Schnitzer/Grunberg 1957, xi, 1. 
the therapy ${ }^{58}$. That there was a problem of how to explain this fact did not hinder them to accept it.

In contrast, insecticide resistance, although discovered and described as early as 1897 , had a hard and long way to go to become generally accepted as a scientific fact in the 1930s. From the first publications on resistance observations to the last handbook article denying scientific respectability to insect resistance more than 30 years went by ${ }^{59}$.

Although they were not well prepared for finding scientific explanations of resistance, many medical-microbiological laboratories helped to keep the professionals aware of resistance as a threat to efficient therapies. However, the public and the general medical doctors were less aware of the risk for public health than the specialists, and prophylactic uses of sulfa drugs that, in the light of resistance knowledge, were abuses, became current. The same applies to penicillin and related antibiotics from the 1940s on. At a time when the biologists in their laboratories oriented towards "fundamental research" still discussed how microbes acquired and transferred resistance by "variation", for application-oriented scientists, especially those working in a clinical context, resistance was a well-known fact and a common problem. While it is too early to decide whether microbiological resistance research was actually clinic driven, it is clear that the statement that medical microbiology did play a less important role in resistance research than "truly biological" (i.e. experimental in the Delbrück, Demerec and Luria style) microbiology is one-sided ${ }^{60}$.

From the history of resistant microbes we learn that a fact can be accepted in a scientific community even before a viable explanation is available. Therefore, it is worth asking why a fact can be accepted as such without any concluding theory or "experimentum crucis". Such a convincing experiment is possible in entomology for resistant insects by selecting resistant individuals from a laboratory population and developing these by further growing them into an "artificial" resistant strain. Such experiments were undertaken in the 1940s and helped understanding DDT-resistance occurring in the field. Beforehand, in 1937, the geneticist Theodosius Dobzhansky had published

58 Schnitzer/Grunberg 1957,1-2.

59 A few entomologists like Smith, Melander, Quayle covered resistant insects in several articles during these decades and proposed a very general explanation by pointing at the effects of selection and inheritance in examples like seed or cattle. Their research practice combined laboratory and field work. See Forgash 1984 and Ceccatti, "Establishing the Fact" 2004. However, the larger community of (in this case American) entomologists did not follow them. Some opponents tried to explain resistance by referring to circumstances like humidity or insect behavior rendering insecticides ineffective.

60 Kohler 1985a, 1985b. 
his influential book on Genetics and the Origin of Species. In this book, he cites resistant insects as a major effect of ongoing selection in the field, and he was able to do so thanks to his contacts with the Californian experiment station in Riverside where Quayle worked on citrus pests resistant towards insecticides.

Angela Creager mentions the Luria-Delbrück experiment and calculation, called the "fluctuation experiment", in the role of "experimentum crucis" in her story. The statistical fluctuation resulting from experiments with bacteria in 1943 showed that inheritance in bacteria cannot be explained by Lamarckian adaptation ${ }^{61}$.

To some extent, such an "experimentum crucis" has not always a decisive and immediate influence on a scientific community. With regard to the history of resistant bacteria, the moment of the Luria-Delbrück fluctuation experiment tends to get the more irrelevant the more we learn about how scientists interpreted the results (if they cared about them). Since most bacteriologists lacked the statistical training the Delbrück group had, they usually were not able to understand the results. Therefore, this experiment was a breakthrough only in a retrospective reconstruction of the history of resistance biology. On the acceptance of resistance as a fact it had no influence (this acceptance reached back into the 19th century), and the actual acceptance of explanations for this fact occurred only by the 1960s.

Entomologists started worldwide resistance research projects only after DDT-resistance had become a universal problem. At the same moment, population genetics became part of a current explanation that definitely established insecticide resistance as a scientifically proven and explained fact. However, while population geneticists were able to explain how a population could develop resistance, biochemistry applied to insect physiology was not yet able to offer more than a general idea why an organism actually could survive in a hostile environment. In this regard, insecticide resistance was not explained before more powerful microanalytical devices became accessible to biochemists, i.e. in the second half of the 1960s. Bridging the gap between genetics and biochemistry was not viable before molecular biology became well established after 1970.

In retrospect, elements from the History of Science like the evolution of disciplines and the introduction of research techniques and related devices, cannot be clearly separated from "ecological" pressures like the practical problems that manufacturers and farmers had with a group of products. The historical moment when a phenomenon was accepted as a scientific fact

61 Luria/Delbrück 1943; Demerec 1945; Luria 1984, 74-79; Brock 1990, 58-63. 
becomes fuzzy. While the discovery can be attributed, at least in most cases, to a group of scientists, a date and a location, its acceptance is a more complex process.

Since the acceptance of a scientific fact as such differs from the story of the discovery, one wonders why it was not possible for insect resistance as well to get acknowledged before an explanation theory was available and widely accepted in the community. Have we to seek an answer outside the history of biology, in the realm of business: more and stronger economic interests dictating the refutation of insect resistance through the lobby of a powerful chemical industry? Or were the applied entomologists who discovered resistant insect strains lacking the scientific "gravitas", influence, and power their counterparts in the medical and chemical profession working for drug discovery had?

Two hypotheses seem most promising at the current state of historical knowledge. (1) Insecticide resistance, however locally important in some regions of the U.S., remained a marginal phenomenon even in the American entomological community as long as insecticides had not become explicitly and to a much larger extent part of an agricultural technology. This happened only when the modern synthetic insecticides of the DDT-era were available. (2) The second hypothesis relies on biological facts that exclude a straightforward comparison between the reception of resistance ideas without considering the biology of insects and bacteria.

\section{Biological facts as causes for divergent knowledge development}

In Part one of the present article we have explored how similarities between insect and microbe resistance can be found by applying historical systemic, ecological, economical, and cultural approaches. In this Part two, we discovered how main approaches of the History of Science (history of biology) can be applied to the insecticide and antibiotic resistance with useful results. However, there are some important biological differences between the organisms in question that affected the history of scientific knowledge on resistance.

Insects reproduce sexually, through mating between males and females, and therefore, through a gene exchange and a sexual reproduction of chromosomes carrying the genetic information in the nucleus of the cells. Mendelian rules apply, and based on them, population dynamics can be combined with statistical genetics into mathematical models that, on the one hand, explain specific phenomena of population dynamics, and, on the other hand, help 
understanding resistance and, therefore, developing resistance avoidance or mitigation tactics.

Bacteria usually reproduce by cell division, and there are many ways of exchanging genetic information. There are also different locations of this information in the cell, not only the DNA in the chromosome but also what sometimes was called "R-factors" located in the cytoplasm ${ }^{62}$. In addition, they are able to exchange genetic material by ways similar to sexual contacts in higher organisms (by conjugation) ${ }^{63}$. Therefore, the conditions for resistance development in such prokaryotes organisms are even more favourable than in higher (eukaryotes) organisms, and the phenomenon has more complex origins, but also more various and more complex ways of spreading resistance genes, even between different species ${ }^{64}$.

Are differences in the history of scientific knowledge determined by such differences in the organisms? Indeed, in part, they are. The population genetics aspect for insects became understandable as soon as population dynamics models were available thanks to Dobzhansky. The molecular biology, as soon as it was sufficiently developed, helped to elucidate the biochemical bases of the reproduction of resistance in a given population of insects. As soon as biochemistry and especially analytical methods were developed, resistance mechanisms in the insect metabolism were understood by the physiologists, at least in principle. The history of resistance knowledge, as far as insects are concerned, and compared to resistant bacteria, was a rather straightforward process. However, it was slow in the beginning, and it was not easy to "see together" population genetics and insect physiology. Overall, some of the fundamentals of insect biology needed to understand resistance were easier to establish, partially because, by 1950, relatively mature knowledge from entomology, Mendelian and population genetics, and chemistry formed a synthesis that made it eventually possible to understand the principles of insecticide resistance (except for more sophisticated biochemistry).

Angela Creager gives an idea of how complex the development of resistance knowledge was for bacteria. The complexity derived from the problems of understanding the nature of reproduction in bacteria and identifying the locations of inheritance information inside them. The story was further

62 A schematic comparison between animal and bacterial cells in U.S. Congress 1995, 35. On the history of discoveries in cytoplasmic heredity, Sapp 1987, Harwood 1984 and 1993. Main contributions on the functions of R-factors came from Japan, especially from Mitsuhashi (1980 and 1993). Cf. Watanabe 1963, Summers 1991, and U.S. Congress 1995, 42. On plasmids, see Lederberg 1998, 4.

63 U.S. Congress 1995, 42.

64 Summary see Amábile-Cuevas 2003,138f. 
complicated by mechanisms like genes that become active (are "turned on") only in presence of stress and other environmental influences, by gene flow across species boundaries, etc. The opposition from the "adaptationist" school in microbiology against the geneticists was, for many years, seemingly more or less justified by the complex behavior of bacteria that did not fit the model of classical genetics. In 1942, even Julian Huxley refused to accept that genetics applied to bacteria ${ }^{65}$.

The comparative delay until most scientists agreed on the basic principles of resistance in bacteria (in the 1960s, as Creager finds) was therefore due to the ambiguous and complex nature of the bacteria. Also the relative lack of maturity of "biological" (fundamental) bacteriology (compared to medical bacteriology) was an effect of this complexity of its objects. This comparative delay had also an influence on the relationship between the medical researchers and the "New Biologists". The medical researchers were able to detect drug resistance at an early time (1939) and monitor resistance phenomena in parallel with the introduction of new antibiotics all through the 1940s to the 1960s and beyond. In contrast, "fundamental biologists" did not offer a consensual set of explanations before the mid-1960s, and important discoveries were still made in the $1990 \mathrm{~s}^{66}$.

Nevertheless, in part, as we already have seen, differences can (or must) also be explained by other influences. Each time resistance was considered a "problem" in real life, by farmers and insecticide manufacturers, by medical practitioners and hospital doctors, by ecologists and state officials under the influence of political environmentalism, resistance research came under the pressure of a "driver" located outside biological laboratories. How far this influence went and how the challenges were reflected by the agendas of research and its various locations, like university, industry, hospital laboratory, state experiment station, still needs more efforts from historical research.

\section{Conclusion}

The historian occupies an appropriate observation point from which insecticide and drug resistance can be compared in order to detect similarities. History, especially when focusing on ecological, economic, or cultural contexts of scientific knowledge, discerns factors promoting or retarding the 
development of insights, both intrinsic (scientific) and external (socioeconomic or cultural), some remaining in the realm of laboratory science, some having effects on industrial product development or consumers' behavior.

In the field of external aspects, there are interests of an industry manufacturing and selling biocide compounds (actually, it was - at least from an European perspective - the same industry: chemical, pharmaceutical) ${ }^{67}$; there are also interests of economic sectors using them, integrating them into their technologies: agriculture, health. State regulation came late: the EC offices discussed in the late 1990s how a study on resistance risks as unwanted side effects should become part of the procedure leading to the introduction of insecticides ${ }^{68}$. Only a few countries regulated the use of antibiotics in the agro-business. The official research programs on antibiotic resistance currently under way in Germany and Switzerland ${ }^{69}$ - to name only these two countries - probably prepare new regulations.

In the field of developments internal to laboratory science, there are aspects of the History of Science common to both types of resistance: the impact of "new" biology, the effects of new analytical methods and devices on physiology and biochemistry (belonging to the 1960s and not explored here), the relationship between field (or clinical) and laboratory studies, and the transgression of boundaries between different fields of specialization.

On both sides, until ca. 20 years ago, the industry was not a major player in resistance research, except for a short period in the 1940s and 1950s when insect resistance against DDT was an important concern. Most companies left this field to universities (and also to experiment stations in the case of insecticide resistance), state officials, and civil movements directed against the chemical- and biology-based technologies mentioned above. This situation changed in the early 1980s when the industry founded IRAC for dealing with insect resistance - is there an organization of the same kind dealing with antibiotic resistance research? When were programs for drug resistance monitoring started? A wide field for more historical research is still open.

67 Also the related chemistry did not differ too much when the first modern insecticides and the antibiotics were developed and introduced in the 1940s and 1950s. In Germany and Switzerland many companies traditionally let the same departments conduct the chemical research on antibiotics as on pesticides. Some authors even believed that a similar match between chemistry and biology was needed for industrial research and development, see Läuger 1944. A differentiation took place, however, when more varied products were at hand, and when state regulation demanded more sophisticated tests before the products went to the public.

68 Urech 1997, Follet 2000.

69 Lode 2001, Swiss National Science Foundation 2000. 


\section{Bibliography}

Amábile-Cuevas, Carlos F., "New Antibiotics and New Resistance”, American Scientist 91 (2003) 138-149

American Academy of Microbiology, Antimicrobial Resistance. An Ecological Perspective. Report from the American Society of Microbiology (Washington 1999)

Amsterdamksa, Olga, "Cyclogenic Theories of Bacterial Variation”, Journal of the History of Biology 24 (1991) 191-222

Austrian, Robert, "The Pneumococcus at the Millennium. Not Down, Not Out", Journal of Infectious Diseases 179, Supplement 2 (1999) 338-341

Bailey, John H./Chester J. Cavallito, “Antibiotics”, Annual Review of Microbiology 2 (1948) $143-182$

Belgian Biosafety Server, Controlling Antibiotic Uses Around the World. http://biosafety.ihe.de/ AR/Links.html (last revised February 22, 2001)

Böschen, Stefan, Risikogenese. Prozesse gesellschaftlicher Wahrnehmungen. FCKW, DDT, Dioxin und ökologische Chemie (Opladen 2000)

- "DDT and the Dynamics of Risk Knowledge Production", Hyle 8 (2002) 79-102

Bosso, Christopher J., Pesticides and Politics. The Life Cycle of a Public Issue (Pittsburgh 1987)

British Medical Journal 317 (1998) 645ff Special Issue on Drug Resistance

Brock, Thomas D., The Emergence of Bacterial Genetics (Cold Spring Harbor/New York 1990)

Brown, Thomas M. (ed.), Molecular Genetics and Evolution of Pesticide Resistance, developed from a symposium sponsored by the ACS Division of Agrochemicals at the Big Sky Conference VI (Washington, D.C. 1996)

Bryan, Lawrence (ed.), Antimicrobial Drug Resistance (Orlando 1984)

Buxtorf, Andreas/Max Spindler (eds.), 15 Years of Geigy Pest Control (Basle 1954)

Ceccatti, John S., "Biological Research in the Chemical Industry: The Case of Insecticide Resistance", Ambix 2004 (in print)

- "Establishing the Fact of Insecticide Resistance in the Field and Laboratory: Research Approaches in Agriculture and Industry", Endeavour: A Quarterly Magazine for the History and Philosophy of Science 2004 (in print)

- "Natural Selection in the Field: Insecticides Resistance and the Evolutionary Synthesis, 1914-1951", submitted to Journal for the History of Biology

Chadwick, Derek J./Jamie Goode, Antibiotic Resistance: Origins, Evolution, Selection and Spread (Chichester 1997)

Clarke, James H./W. S. Clark/M. Hancock, "Strategies for the Prevention of Development of Pesticide Resistance in the U.K.”, Pesticide Science 51 (1997) 391-397

Crawford, L. M./E. B. Shotts, "Animal Uses of Antibiotics as Feed Additives and in Therapy and the Emergence of Antibiotic-Resistance", in: Charles H. Stuart-Harris/David M. Harris (eds.), The Control of Antibiotic-Resistant Bacteria (London 1982) 169-181

Creager, Angela N. H., "Adaptation or Selection? Old Issues and New Stakes in the Postwar Debates about Microbial Drug Resistance", Draft of a forthcoming article (2002)

Demerec, Milislav, "Production of Staphylococcus Strains Resistant to Various Concentrations of Penicillin", Proceedings of the National Academy of Sciences, USA, 31 (1945) $16-24$

Doberstyn, E. B., "Resistance to Antimalarial Agents", in: L. E. Bryan (ed.), Antimicrobial Drug Resistance (Orlando 1984) 461-485

Dobzhansky, Theodosius, Genetics and the Origin of Species (New York 1937)

Dowling, Harry F., Fighting Infection. Conquests of the 20th Century (Cambridge, Mass. 1977)

European and Mediterranean Plant Protection Organisation (EPPO), 6th Meeting of the Panel on Resistance Risk Assessment (Madrid, 2002-02-12/13), http://www.eppo.org/MEETINGS/ 2002_meeting/resistance.html

Fidler, David P., "Legal Issues Associated with Antimicrobial Drug Resistance", Emerging Infectious Diseases 4 (1998) 169-177

Fleck, Ludwik, Genesis and Development of a Scientific Fact, ed. by Thaddeus J. Trenn and Robert K. Merton (Chicago 1979)

Follet, Ghislain, "Antibiotic Resistance in the EU. Science, Politics, and Policy", AgBioForum 3 (2000) 148-155 
Forgash, Andrew J., "History, Evolution, and the Consequences of Insecticide Resistance", Pesticide Biochemistry and Physiology 22 (1984) 178-186

Frisch, A. W. et al., "Type VIII Pneumococcus. Development of Sulfadiazine Resistance", Ann. Intern. Med. 18 (1943) 271-278

Georghiou, G. P., "The Magnitude of the Resistance Problem", in: Pesticide Resistance, Strategies and Tactics for Management. National Research Council (Washington, D.C. 1986) 14-44

Gradmann, Christoph, "Isolation, Contamination, and Pure Culture. Monomorphism and Polymorphism of Pathogenic Micro-Organisms as Research Problem, 1860-1880", Perspectives on Science 9 (2000) 147-172

Hamburger, M. et al., "The Occurrence of Sulfonamide-Resistant Pneumococci in Clinical Practice”, Journal of Infectious Diseases 73 (1943) 12-30

Harwood, Jonathan, "The Reception of Morgan's Chromosome Theory in Germany. Inter-War Debate over Cytoplasmic Inheritance", Medizinhistorisches Journal 19 (1984) 3-32

- Styles of Scientific Thought. The German Genetics Community 1900-1933 (Chicago 1993)

Hohlfeld, Rainer, "Ein Abschluss des Forschungsprogramms der experimentellen Biologie. Bioengineering", in: Rüdiger Inhetveen/Rudolf Kötter (eds.), Forschung nach Programm? (München 1994) 113-128

Hughes, Diarmaid/Dan I. Andersson, Antibiotic Development and Resistance (London 2001)

Huxley, Julian, Evolution, the Modern Synthesis (Cambridge 1942)

Kellenberger, Eduard, "Die Biologie von morgen”, Schweizerische Hochschulzeitung 43 (1970) $34-58$

Kohler, Robert E., "Bacterial Physiology. The Medical Context", Bulletin of the History of Medicine 59 (1985a) 54-74

- "Innovation in Normal Science. Bacterial Physiology", Isis 76 (1985b) 162-181

- Lords of the Fly. Drosophila Genetics and the Experimental Life (Chicago 1994)

Krementsov, Nicolai, "A 'Second Front' in Soviet Genetics. The International Dimension of the Lysenko Controversy, 1944-1947", Journal of the History of Biology 29 (1996) 229-250

- Stalinist Science (Princeton 1997)

Läuger, Paul/Henri Martin/Paul Müller, "Über Konstitution und toxische Wirkung von natürlichen und neuen synthetischen insektentötenden Stoffen", Helvetica Chimica Acta 27 (1944) 892-928

Law, John, "Networks, Relations, Cyborgs. On the Social Study of Technology". Online paper, Centre for Science Studies at Lancaster University (June 16, 2000) http://www.comp.lancs.ac. uk/sociology/soc042jl.html

Lederberg, Joshua, "Personal Perspective - Plasmid 1952-1997”, Plasmid 39 (1998) 1-9

Leonard, Paul K., "Resistance Risk Evaluation. A European Regulatory Perspective", http:// plantprotection.org/irac/international/Regulatory_Team/PoznanArticle.htm

Levy, Stuart B., The Antibiotic Paradox. How Miracle Drugs Are Destroying the Miracle (New York 1992)

Levy, Stuart B./Richard P. Novick (eds.), Antibiotic Resistance Genes. Ecology, Transfer, and Expression, Banbury Report 24 (Cold Spring Harbor 1986)

Lewis, Kim/Abigail A. Salyers/Harry W. Taber/Richard G. Wax (eds.), Bacterial Resistance to Antimicrobials (New York 2002)

Lode, Hartmut/Ernst Mutschler/Bernd Wiedemann (eds.), Bakterielle und virale Resistenz. Epidemiologie, Mechanismen, klinische Relevanz und therapeutische Konsequenzen. Symposium der Akademie der Wissenschaften und der Literatur Mainz, 3./4.12.1999 (Basel 2001)

Lubrano, Linda L./Susan Gross Solomon (eds.), The Social Context of Soviet Science (Boulder, Colo. 1980)

Luria, Salvador E., A Slot Machine, a Broken Test Tube. An Autobiography (New York 1984)

Luria, Salvador E./Max Delbrück, "Mutations of Bacteria from Virus Sensitivity to Virus Resistance", Genetics 28 (1943) 491-511

Lutz, Peter L., The Rise of Experimental Biology. An Illustrated History (Totowa, N.J. 2002)

Matagne, Patrick, Comprendre l'écologie et son histoire. Les origines, les fondateurs et l'évolution d'une science (Paris 2002)

Mayr, Ernst, The Growth of Biological Thought. Diversity, Evolution, and Inheritance (Cambridge, Mass. 1982) 
McKenzie, John A., Ecological and Evolutionary Aspects of Insecticide Resistance (Austin, Tex. 1996)

Mitsuhashi, S., "Drug Resistance in Bacteria. History, Genetics and Biochemistry", Journal of International Medical Research 21 (1993) 1-14

Mitsuhashi,Susumu/L. Rosival/V.Krčméry (eds.), Antibiotic Resistance. Transposition and Other Mechanisms. Fourth International Symposium on Antibiotic Resistance, Castle of Smolenice, Czechoslovakia 1979 (Prague 1980)

Morange, Michel, A History of Molecular Biology (Cambridge, Mass. 2000)

National Academy of Sciences (USA)/National Research Council, Conference on Insecticide Resistance and Insect Physiology. National Research Council Publication 219 (Washington, D.C. 1951)

Olby, R. C./Geoffrey N. Cantor/J. R. R. Christie/M. J. S. Hodge (eds.), Companion to the History of Modern Science (London 1990)

Palsson, Katinka, Ecology and Control of Anopheles Mosquitoes and Human Malaria in GuineaBissau, West Africa (Uppsala 1999)

Perkins, John H., Insects, Experts, and the Insecticide Crisis (New York 1982)

Pieroth, Ingrid, Penicillinherstellung. Von den Anfängen bis zur Großproduktion (Stuttgart 1992)

Pimentel, David/Hugh Lehmann (eds.), The Pesticide Question. Environment, Economics, and Ethics (New York 1993)

Rosner, Lisa (ed.), The Technological Fix:Visions, Trials, and Solutions (New York/London 2004) (in print)

Roush, Richard T./Bruce E.Tabashnik (eds.), Pesticide Resistance in Arthropods (New York 1990)

Sabath, L. D., "Emergence of Bacterial resistance to Antibiotics Occurring during Therapy", in: Charles H. Stuart-Harris/David M. Harris (eds.), The Control of Antibiotic-Resistant Bacteria (London 1982) 17-33

Sapp, Jan, Beyond the Gene. Cytoplasmic Inheritance and the Struggle for Authority in Genetics (Oxford/New York 1987)

Schmidt, L. H./C. L. Sessler, "Development of Resistance to Penicillin by Pneumococci", Proceedings Soc. Exp. Biol. Med. 52 (1943) 553-557

Schnitzer, Robert J./Emanuel Grunberg, Drug Resistance of Microorganisms (New York 1957)

Serres, Michel (ed.), A History of Scientific Thought. Elements of a History of Science (London 1995)

Simon, Christian, "DDT - Forschung und Entwicklung zwischen Chemie und Biologie. Ein Beitrag zur Geschichte der Wissensproduktion", in: Thomas Busset/Andrea Rosenbusch/ Christian Simon (eds.), Chemie in der Schweiz. Geschichte der Forschung und der Industrie (Basel 1997) 180-212

- DDT. Kulturgeschichte einer chemischen Verbindung (Basel 1999)

Sjut, Volkert (ed.), Molecular Mechanisms of Resistance to Agrochemicals (Berlin 1997)

Spencer, Larry T., "An Annotated Bibliography of Books Dealing with the History of Ecology" (Plymouth State College 1999) http://oz.plymouth.edu/ lts/ecology/ecohistory/bibliography. html

Stent, Gunther S./Richard Calendar, Molecular Genetics. An Introductory Narrative (San Francisco $\left.{ }^{2} 1978\right)$

Stettler, Niklaus, Natur erforschen. Perspektiven einer Kulturgeschichte der Biowissenschaften an Schweizer Universitäten 1945-1975 (Zürich 2002)

Stollerman, Gene H. "The Global Impact of Penicillin. Then and Now", Mount Sinai Journal of Medicine 60 (1993) 112-119

Stuart-Harris, Charles H./David M. Harris (eds.), The Control of Antibiotic-Resistant Bacteria (London 1982)

Summers, William, "From Culture as Organism to Organism as Cell. Historical Origins of Bacterial Genetics", Journal of the History of Biology 24 (1991) 171-190

Swiss National Science Foundation, NRP 49 Antibiotic Resistance. Implementation Plan (Berne 2000) www.snf.ch/nfp49

Townsend, Colin R.T./Michael Begon/John L. Harper, Essentials of Ecology (Malden, Mass. 2000)

Trepl, Ludwig, Geschichte der Ökologie. Vom 17. Jahrhundert bis zur Gegenwart. 10 Vorlesungen (Frankfurt/Main 1987) 
- "Zur Geschichte des Umweltbegriffs", Die Naturwissenschaften 79 (1992) 386-392

Urech, Pierre A./T. Staub/G. Voss, "Resistance as a Concomitant of Modern Crop Protection", Pesticide Science 51 (1997) 227-234

U.S. Congress, Office of Technology Assessment, Impacts of Antibiotic-Resistant Bacteria, OTA-H-629 (Washington, D.C. 1995)

(U.S.) FDA, Center for Veterinary Medicine, "A Proposed Framework for Evaluating and Assuring the Human Safety of the Microbial Effects of Antimicrobial New Animal Drugs Intended for Use in Food-Producing Animals", Federal Register (January 6, 1999)

(U.S.) Interagency Task Force on Antimicrobial Resistance, A Public Health Action Plan to Combat Antimicrobial Resistance (Washington, D.C. 1999)

Vose, David/J. Acer/F. Anthony/A. Franklin/R. Gupta/T. Nicolls/Y. Tamura/S. Thompson/ E. J. Threlfall/M. van Vuuren/D. G. White/H. C. Wegener/M. L. Costarrica (Ad-hoc Group of Experts on Antimicrobial Resistance, Appointed by the Office International des Epizooties), "Antimicrobial Resistance. Risk Analysis Methodology for the Potential Impact on Public Health of Antimicrobial Resistant Bacteria of Animal Origin", Rev. sci. tech. Off. Int. Epiz. 20 (2001) 811-827

Watanabe, Tsutomu, "Infective Heredity of Multiple Drug Resistance in Bacteria", Bacteriological Reviews 27 (1963) 87-115

White, Hayden, The Content of the Form. Narrative Discourse and Historical Representation (Baltimore 1987)

Whorton, James C., Before Silent Spring. Pesticides and Public Health in Pre-DDT America (Princeton 1974)

Wolstenholme, G. E. W./Cecilia M. O'Connor (eds.), Ciba Foundation Symposium on Drug Resistance in Micro-Organisms. Mechanisms of Development (Boston 1958)

World Health Organization, www.who.int/infectious-disease-report/2000 (2000) 